\title{
Har pasienten virkelig hypertensjon?
}

\author{
Blodtrykksmålingens metodologi ignoreres. Sannsynligvis er det mange i dag som ikke burde fått \\ antihypertensiver.
}

Jeg er en gammel internist som ennå preges av kunnskap fra turnustjenesten i 1956 ved Bodø sykehus. Dette var den fremste kardiologiske avdeling i Norge på den tiden, og guruen Ole Storstein (1909-98) lærte

\section{«Ole Storstein graderte hypertensjonssykdom- men slik: hypertensio arterialis levis, hyper- tensio arterialis gravis og hypertensio arterialis maligna»}

oss nøyaktighet og stringens i det kliniske arbeidet. Fabelaktig fagmann! Nå ønsker jeg kommentarer, helst korreksjoner, til min påstand om at blodtrykksmålingens metodologi ignoreres. Jeg tror det finnes mange pasienter som ikke burde vært behandlet med antihypertensiver.

\section{1 sentrale spørsmål}

- Blir blodtrykksapparatene sjekket regelmessig?

- Måles blodtrykket på begge armer?

- Gjøres det måling over et helt døgn?

- Tas det hensyn til omkrets på overarm og mansjettstørrelse?

- Tas det hensyn til at ved visse sykdommer (og ved høy alder) er arteriens media tykkere og stivere enn vanlig og det kreves høyere trykk for å komprimere arterien?

- Gjøres det alltid oftalmoskopi ved mistanke om hypertensjon?

- Tas det alltid EKG ved slik mistanke?

- Hvordan vurderes blodtrykksmålingene hos en pasient med atrieflimmer, siden trykket selvsagt varierer med slagvolum?

- Undersøkes pasienten med tanke på at hypertensjonen kan være sekundær til annen sykdom?

- Hvor ofte kontrolleres et blodtrykk med intraarteriell måling?

- Prøves effekten av saltrestriksjon før farmakoterapien?

Ole Storstein graderte hypertensjonssykdommen slik: hypertensio arterialis levis, hypertensio arterialis gravis og hypertensio arterialis maligna. Dette er en meget nyttig klassifikasjon som har konsekvenser for valg av terapeutisk innsats.

Jeg er redd for at man i dag legger for stor vekt på en gradering som er basert på tall målt under tvilsomme metodologiske forutsetninger. Er det noen der ute som kan berolige meg?

Antakelig kan samfunnet spare enorme ressurser ved å rydde opp i dette store problemet.

\section{Carl Ditlef Jacobsen \\ $c d-j @ o n l i n e . n o$}

Carl Ditlef Jacobsen (f. 1930) er pensjonert overlege og spesialist $\mathrm{i}$ indremedisin og i fordøyelsessykdommer. Forfatter har fylt ut ICMJE-skjemaet og oppgir ingen interessekonflikter.

Mottatt 8.8. 2012 og godkjent 16.8. 2012. Medisinsk redaktør Erlend Hem. 